\title{
IDEOLOGICAL DISCOURSE ANALYSIS IN SOVIET ANIMATION CINEMA
}

\author{
Koray SEVINDI* \\ İstanbul Medeniyet University, Turkey \\ koraysevindi@gmail.com \\ https://orcid.org/0000-0003-0264-5390
}

\author{
Atıf Sevindi, K. (2021). IDEOLOGICAL DISCOURSE ANALYSIS IN SOVIET ANIMATION \\ CINEMA. The Turkish Online Journal of Design Art and Communication, 11 (2), 594-605.
}

\begin{abstract}
In this study, the Soviet animation cinema's ideological discourses, which showed the consequences and reflections of the political ideology of the era, were examined. In line with the findings, it was considered that these animated films constitute a kind of cultural memory that exhibits the political history and social culture of the Soviets. The article's ideological discourse analysis method was applied by considering Teun A. van Dijk's study titled Ideological Discourse Analysis. As part of this research, because ideological discourses were analyzed, only short films with propaganda content were regarded among Soviet animations, and the scope of the study was restricted. Furthermore, the date range taken about the films was the term of Soyuzmultfilm, the official animation studio of the Soviet Union. The films created by the studio, which began its actions in 1936 until the dissolution of the Soviet Union in 1991, were taken into account. The conclusions of discourse analysis were evaluated according to the headings 'self-identity', 'activity', 'goal', 'norm and value', 'position and relation' and 'resource' mentioned in the article Ideological Discourse Analysis, and the ideological discourses in Soviet animated cinema were analyzed.
\end{abstract}

Keywords: Animation, Propaganda, The Soviet Union, Discourse Analysis, Socialism.

\section{SOVYET ANIMASYON SINEMASINDA IDEOLOJIKK SÖYLEM ÇÖZÜMLEMELERI}

\section{ÖZ}

Bu çalışmada, dönemin siyasal ideolojisinin etkilerini ve yansımalarını gösteren Sovyet animasyon sinemasının ürettiği ideolojik söylemler incelenmiş, bulunan bulgular doğrultusunda bu animasyon filmlerin Sovyetlerin siyasal tarihini ve toplumsal kültürünü yansıtan bir çeşit kültürel hafiza oluşturduğu irdelenmiştir. Makaledeki ideolojik söylem analizi yöntemi Teun A. van Dijk'in Ideological Discourse Analysis başlıklı makalesi dikkate alınarak uygulanmıştır. Çalışma kapsamında ideolojik söylemler incelendiği için Sovyet animasyonları arasında yalnızca propaganda içerikli olan kısa filmler ele alınmış ve çalışmanın kapsamı sınırlandırılmıştır. Ayrıca filmlerle ilgili alınan tarih aralığı Sovyetler Birliği’nin resmi animasyon stüdyosu olan Soyuzmultfilm dönemidir. 1936 yılında faaliyetlerine başlayan stüdyonun 1991 yılında Sovyetler Birliği'nin dağılmasına kadar geçen sürede ürettiği filmler dikkate alınmıştır. Söylem analizinde bulunan bulgular Ideological Discourse Analysis makalesinde belirtilen 'öz-kimlik', 'aktivite', 'hedef', 'norm ve değer', 'konum ve ilişki' ve 'kaynak' başlıkları üzerinden değerlendirilmiş ve Sovyet animasyon sinemasındaki ideolojik söylemler çözümlenmiştir.

Anahtar Kelimeler: Animasyon, Propaganda, Sovyetler Birliği, Söylem Analizi, Sosyalizm

* "This article is derived from the Ph.D. thesis titled 'Ideological Discourse in Soviet Propaganda Animated Films' prepared by Koray Sevindi in the Cinema Doctorate Program of Marmara University, Turkey."

Research Article - This article was checked by iThenticate 


\section{INTRODUCTION}

Propaganda has obtained a position in every period in history when communication and interaction exist. Diplomatic battles have substituted physical struggles, and the significance of propaganda has grown from day to day. It is not merely regarding the scope of communication; it is about history because of its historical perspective, sociology due to its one-on-one relationship with society, psychology owing to the oppression and manipulation it applies to the individual, and various additional fields. The relation of cinema with politics could be considered in two approaches. The first is propaganda cinema, which prioritizes the object rather than aesthetic concern, and prefers a straight and didactic narrative. The second is political cinema, which concentrates on cinema's artistic side, more implicity subjects the reflections of sovereign ideologies on community and culture, and does not underestimate cinema's commercial side.

Cinema has been utilized as a propaganda factor since its first appearance. The propaganda films, which rose primarily throughout the two great world wars and the Cold War, provided an unusual subconscious war in addition to the hot war between the nations. In particular, the activities practiced by the Soviet Union in internal and external propaganda with special attention were additionally carried out through animated films. The relationship of animation with the children's entertainment world, the fact that its structural background is more convenient for metaphorical storytelling, and allowing propaganda more implicit were prominent factors in this decision. In this article, the characteristics of propaganda animation filmmaking, which the Soviets implemented since the 1920s and maintained until the end of the Cold War era, were investigated, and the ideological discourses of Soviet propaganda animation were examined.

The article's ideological discourse analysis method was applied by considering Teun A. van Dijk's study titled Ideological Discourse Analysis. In the referenced article, ideology is defined as systems based on the socio-political cognition of groups. For this reason, ideologies have social groups with schematically organized general viewpoints on a subject, and each group introduces its own values and builds the basic units for group ideologies. Van Dijk asserts that there is a requirement for a bridge between social cognition and individual cognition, consisting of personal knowledge and experience, in these groups, and ideologies influence the information and beliefs of individual users within social representations such as attitudes or socio-cultural knowledge $(1995: 138,146)$.

As part of this research, because ideological discourses were analyzed, only short films with propaganda content were regarded among Soviet animations, and the scope of the study was restricted. In the detection of these movies, The Encyclopedia of Local Animation (Kapkov, 2006) and Animator.ru animation database, supported by the Federal Agency of the Press and Mass Media of the Russian Federation, were referenced. Furthermore, the date range taken about the films was the term of Soyuzmultfilm, the official animation studio of the Soviet Union. The films created by the studio, which began its actions in 1936 until the dissolution of the Soviet Union in 1991, were taken into account. The conclusions reached from films that were produced for propaganda goals has been examined in line with van Dijk's approach to ideological groups' representation of members, friends, allies, or supporters in a 'positive' style, in contrast, groups outside them, enemies or opponents were portrayed in a 'negative' form. The findings of discourse analysis were evaluated according to the headings 'self-identity', 'activity', 'goal', 'norm and value', 'position and relation' and 'resource' mentioned in the article Ideological Discourse Analysis, and the ideological discourses in Soviet animated cinema were analyzed.

\section{AN OVERVIEW OF SOVIET PROPAGANDA ANIMATED FILMS}

In addition to its merely 'entertaining' mission having in its beginning years, cinema has become a 'tool' that has been fed by various disciplines such as sociology, psychology, politics, and philosophy, on which academic researches have been executed, its manipulative side has been discovered, and which

Research Article - This article was checked by iThenticate 
is frequently used in political propaganda activities. Animation, as a sub-genre, also contributed to this improvement process of cinema. Its comprehensive narrative capability, the stylistic structure that can easily manipulate the audience, and appeal to a broad age range increase animation's propagandistic practices. Although the Soviets are better recognized for their live-action movies, for example, Battleship Potemkin (1925), they are crucial in applying animation as a political component.

The Soviet Union produced many influential animated works pioneered in the world before the propaganda era started in the 1920s. The Soviet Union's first animator was Alexander Shiryaev, who used animation to teach dance techniques. Shiryaev, who is considered to have created these dance movies between 1906 and 1909, made the earliest examples of puppet animation in the world, and no one was aware of these films until their discovery in 1995 (Bocharov, 2004). Another primary name of the Soviets in animation was Ladislas Starevich, who contributed to the spread of stop-motion as a genre. He began his film productions by preparing documentaries at the local Ethnography Museum. His first work was reenacting a local insect species' nocturnal mating ritual that could not be recorded in the dark. In the first movie producing for entertainment, he developed the puppet making technique that he would use throughout his lifetime (Moritz, 1997: 76). The stop motion film The Beautiful Leukanida (1912), created by Starevich using cockroaches, was an instance of black humor. Following the film's English screening, London newspapers reported that the insects were real and trained by an unnamed Russian scientist (Bendazzi, 1995: 36). Starevich, who dealt with horror elements emotionally with this type of film, produced many works with his strange and exciting stories and inspired several directors, notably Tim Burton and the Quay Brothers (Sawicki, 2010:73). After the Bolshevik Revolution, animation, like cinema, was also under the authority of the state mechanism, and movies shaped by the state, some of which were for propaganda plans, began to be produced. While Dziga Vertov's Soviet Toys (1924) was one of the earliest Soviet animated films, Senka the African (1927) was the first animation for children. The movie The Post (1929), directed by Mikhail Tsekhanovsky and telling the story of a mail's transportation, was also viral during its time, and shown outside the country and differentiated with its avant-garde style (Bendazzi, 1995: 47). In 1935, The New Gulliver, a communist remake of Jonathan Swift's book Gulliver's Travels and the first feature-length animation of the Soviet Union, combined the live-action with the stop motion technique and was used approximately 3000 different puppets.

Soviet animation was an ecole that emerged within the state's political power frame and used animation creation opportunities. The process that originated with the stop motion technique switched to traditional animation, film production became more systematic in the 1930s with the impact of Disney movies, and the rotoscope method was also applied a lot under the weight of Socialist Realism. It was a cinema that points at people on its own country's borders, where functional objects rather than artistic concerns came to the fore, so it was not very well known internationally. Works in the propagandistic structure were not displayed with purely didactic details; due to animation's narrative chances, allegorical and metaphorical stories were also used from time to time. As Sergei Eisenstein noted, art in the Soviet Union was no separate from metallurgical science or material processing (1993: 25). Hence, the films' primary objectives were to introduce the Soviet people to the political environment they are located and protect the existing government authorization by vilifying the opposing forces. Here, the universal composition of cinema, the fact that it was immediately portable and reproducible, the visual strength that eliminates language, and its ability to convey whatever is desired even to the illiterate public were essential features. It was observed that animations also obeyed the government's ideological, political, social, and psychological desires.

In the Soviet Union, the concept of propaganda was applied in three approaches: spreading ideas, values, and knowledge to improve people's worldview (information propaganda); explaining the ideologies and principles of states (political propaganda); to fight against anti-state or anti-communist bourgeois propaganda (counter-propaganda). In the information propaganda, some thoughts and issues were submitted to the Soviet society from the authorities' perspective through mass media such as newspapers

Research Article - This article was checked by iThenticate 
and magazines. In the political propaganda, all the details of the state's movements and the party both in the country and the international arena were conveyed to the Soviet people. The speakers carried out these actions to promote socialist ideology and political orientation in various enterprises, educational and cultural institutions, farms, industrial and technical schools. Counter propaganda proceeded along a line attempting to preserve the power of communist propaganda, blocking the views and activities of capitalist countries, focusing on the 'decay' of capitalism and the crimes of bourgeois countries against both their people and those in other countries (Lozhkov, 2013: 189-190).

The propaganda animated films designed by the Soviets commonly aimed to denigrate the Western image, particularly the USA, and capitalism. In these films, capitalists, bourgeois, landowners, priests, spies, and counter-revolutionaries were satirized as 'enemies' and portrayed as villains. The settled goodbad conflict was based on the opposition between individual and society (Taylor, 1998: 52). Two separate groups were formed as 'we' and 'they' in the movies, and the expression 'they' was based on two elements: anti-Western built in the connection of capitalism and imperialism, and anti-Nazi created in the context of fascism. The expression 'we' was based on bringing socialism and communism to the fore, spreading and rooting them. In this meaning, it has been observed that propaganda animated films could be united under three principal headings: 'Movies against Capitalism and Imperialism', 'Anti-Fascist Movies', and 'Films in Praise for Socialism and Communism' (Sevindi, 2020:147).

\section{METHODOLOGY}

In his article titled Ideological Discourse Analysis, Teun A. van Dijk describes ideology as systems based on groups' socio-political cognition. Consequently, there are social groups in ideologies that have schematically formed general beliefs on a subject, and each group introduces its values and builds the units for group ideologies. Van Dijk states that, in these groups, there is a need for a connection between social cognition and personal cognition, which consists of personal knowledge and practices, and ideologies, such as attitudes or socio-cultural knowledge, affect the culture and beliefs of individual users within social representations. He emphasizes that ideological discourse analysis is not only aimed at identifying basic ideologies, but discourse semantics can be affected by ideologies both at the microlevel in terms of words and sentences and at the macro level in general. He also maintains that the association of discourse structures with ideology structures is also an object of this analysis (1995: 138, 146). From this point of view, it can be assumed that findings on the creation of enemies and glorification of the existing order fit van Dijk's approach to ideological groups' representation of members, friends, allies, or supporters in a 'positive' way, and groups outside them, enemies or rivals in a 'negative' way. Thus, when the action comes as an in-group activity, it is directly and thoroughly emphasized and enriched with supporting materials; when the same action comes from outside the group, it is indirect, emptied, and transmitted without support. In this way, meanings are structurally manipulated by innergroup nepotism and outer-group derogation (van Dijk, 1995: 143). The study's discourse analysis will also be based on these distinctions between internal and external groups within the identified themes.

Besides, Norman Fairclough's Critical Discourse Analysis as a Method in Social Scientific Research was also respected. According to Fairclough, critical discourse analysis is a theoretical perspective that grants broad analysis possibilities for language and, more regularly, semiosis, which is an indicator/sign process. It is a method that establishes a dialogic relationship with other social theories and techniques, can change the boundaries between different approaches and methods with a supra-disciplinary rather than interdisciplinary, is admissible to other theoretical reasonings, and can 'interiorize' them. Fairclough bases his critical discourse analysis on the semiosis view, including all forms of meaning-making such as visual images, body language, and language. This method examines the dialectical relationships between elements of other social practices and semiosis, including language. He declares that social life can be seen as a network in which the social practices of various fields, such as economy, politics, culture, are connected, and each field has a semiotic element (Fairclough, 2001: 121-122). This view also supports the point of view discussed in the study.

Research Article - This article was checked by iThenticate 
In his same work, van Dijk states that if ideological discourses are structured as categories of group schema as mentioned before, they are aimed at some issues, meanings, and inferences from a semantic point of view and answer the questions asked under these topics:

Self-Identity: Who are 'We'? Who are those who belong to 'We' and those who do not? What is 'Our' history? What is our difference from others? What are 'We' proud of? In this title, features such as gender, race, ethnicity, age, religion, language, and origin are at the forefront.

Activity: What have 'We' done? What are 'Our' activities? What is expected of "Us"? What are 'Our' social roles? This topic focuses on groups and activities that stand out for their actions, such as activists.

Goal: What are the objectives of the activities? This title assumes that the ideological and social sensitivity of activities can be possible with purposes. 'Good' goals involve, for example, informing the public, serving as a watchdog (journalists), seeking the truth, educating young people (professors), or saving nature (environmentalists).

Norm and Value: What norms and values do 'We' conform to these activities? What is good or bad for 'Us', right or wrong? For example, the emphasis is placed on enemies or opponents for violating norms and values. Thus 'others' are reduced to the position of undemocratic, intolerant, inefficient, rude, and mindless.

Position and Relation: Which groups are 'We' connected with? Who are 'Our' friends and enemies? Conflict, polarization, or derogation are evaluated under this heading since groups define their identities, activities, and goals mostly through their relations with other groups.

Resource: What are the sources that 'Our' have or do not have privileged access to? This title emphasizes that groups can create ideological discourse through sources such as knowledge, expertise, status, respect, work, income, housing that they have or do not have (1995:147-149).

Decisions to be defined in terms of ideology in the discourse analysis will be evaluated within the framework of the above titles and questions, and the diversity made over 'we' and 'they' will be discussed in terms of the determined themes. These categories are in line with the films reviewed: location, personage-character, costume-accessory, business life-economy, social features-historical events, religion, and symbol-brand. Moreover, considering the study is cinema research, to answer the 'how?' question in the discourse, some themes proper for the cinema's visual and auditory language were attached.

To determine the scanned movies, The Encyclopedia of Local Animation prepared by Sergey Kapkov and Animator.ru animation database (URL-1), including Kapkov as the main editor and backed by the Federal Agency of Press and Mass Media of the Russian Federation, was consulted. In these circumstances, 55 of the 1329 films produced under Soyuzmultfilm between 1936-1991 were discovered to be propaganda films. The video records of 10 of them could not be reached, but the remaining 45 were accessed, and all were involved in the analysis. The list of these movies is presented below. 
Table 1. List of propaganda animated films produced between 1936-1991 and included in discourse analysis

\begin{tabular}{|c|c|c|c|}
\hline Year & Film Title (English) & Original Title (Russian) & Director \\
\hline 1939 & Combat Pages & Boyevyye Stranitsy & Dmitry Babichenko \\
\hline 1939 & Victory Route & Pobednyy Marshrut & $\begin{array}{c}\text { Dmitry Babichenko } \\
\text { / Leonid Amalrik / } \\
\text { Vladimir } \\
\text { Polkovnikov }\end{array}$ \\
\hline 1940 & Ivas & Ivas' & Ivan Ivanov-Vano \\
\hline 1941 & $\begin{array}{l}\text { Fascist Boot Won't } \\
\text { Trample the Soil of Our } \\
\text { Motherland }\end{array}$ & $\begin{array}{l}\text { Ne Toptat' Fashistskomu } \\
\text { Sapogu Nashey Rodiny }\end{array}$ & $\begin{array}{l}\text { Ivan Ivanov-Vano / } \\
\text { Alexander Ivanov }\end{array}$ \\
\hline 1941 & Vultures & Stervyatniki & $\begin{array}{l}\text { Panteleimon } \\
\text { Sazonov }\end{array}$ \\
\hline 1941 & Hitler Wants That & Chego Gitler khochet & Ivan Ivanov-Vano \\
\hline 1941 & Do Beat Fascist Pirates & Bey fashistskikh piratov & Olga Khodataeva \\
\hline 1941 & $\begin{array}{l}\text { Do Beat the Enemy at } \\
\text { the Front and in the } \\
\text { Rear of the Enemy }\end{array}$ & $\begin{array}{l}\text { Bey vraga na fronte i v } \\
\text { tylu }\end{array}$ & $\begin{array}{l}\text { Valentina Brumberg } \\
\text { / Zinaida Brumberg }\end{array}$ \\
\hline 1941 & A Strong Handshake & Krepkoye rukopozhatiye & Alexander Ivanov \\
\hline 1941 & $\begin{array}{c}\text { We Beat, Beat and Will } \\
\text { Beat }\end{array}$ & Bili! B'yom! Budem bit'! & Dmitry Babichenko \\
\hline 1942 & Cinema-Circus & Kinotsirk & $\begin{array}{l}\text { Olga Khodataeva / } \\
\text { Leonid Amalrik }\end{array}$ \\
\hline 1947 & For You, Moscow & Tebe, Moskva! & Grigory Lomidze \\
\hline 1947 & $\begin{array}{l}\text { An Adventure in the } \\
\text { Land of Giants }\end{array}$ & $\begin{array}{c}\text { Puteshestviye v stranu } \\
\text { velikanov }\end{array}$ & Dmitry Babichenko \\
\hline 1948 & Mashenkas Concert & Mashen'kin kontsert & $\begin{array}{c}\text { Mstislav } \\
\text { Pashchenko }\end{array}$ \\
\hline 1949 & A Strange Voice & Chuzhoy Golos & Ivan Ivanov-Vano \\
\hline 1949 & Mister Wolf & Mister Uolk & Victor Gromov \\
\hline 1949 & The Ambulance & Skoraya pomoshch' & Lamis Bredis \\
\hline 1957 & A Realised Dream & $\begin{array}{c}\text { Voploshchonnaya } \\
\text { mechta }\end{array}$ & Nikolai Fedorov \\
\hline 1958 & $\begin{array}{c}\text { The Tale About Boy- } \\
\text { Kibalchish }\end{array}$ & $\begin{array}{l}\text { Skazka o Mal'chishe- } \\
\text { Kibal'chishe }\end{array}$ & $\begin{array}{c}\text { Alexandra Snezhko- } \\
\text { Blotskaya }\end{array}$ \\
\hline 1960 & $\begin{array}{l}\text { Read It and Go to Paris } \\
\text { and China }\end{array}$ & $\begin{array}{c}\text { Prochti i katay v Parizh i } \\
\text { Kitay }\end{array}$ & $\begin{array}{c}\text { Theodor } \\
\text { Bunimovich / } \\
\text { Anatoly Karanovich }\end{array}$ \\
\hline 1961 & An Expensive Copeck & Dorogaya kopeyka & Ivan Aksenchuk \\
\hline 1961 & An Overseas Reporter & Zaokeanskiy reportor & Grigory Lomidze \\
\hline 1962 & A Celestial Story & Nebesnaya Istoriya & $\begin{array}{l}\text { Youry Prytkov } \\
\text { / Vitold } \\
\text { Bordzilovsky }\end{array}$ \\
\hline 1963 & Shareholders & Aktsionery & Roman Davydov \\
\hline 1963 & Mister Twister & Mister Tvister & Anatoly Karanovich \\
\hline
\end{tabular}

Research Article - This article was checked by iThenticate 
The Turkish Online Journal of Design, Art and Communication - TOJDAC ISSN: 2146-5193, April 2021 Volume 11 Issue 2, p.594-605

\begin{tabular}{|c|c|c|c|}
\hline 1963 & The Millionaire & Millioner & $\begin{array}{l}\text { Vitold Bordzilovsky } \\
\text { / Youry Prytkov }\end{array}$ \\
\hline 1963 & An African Tale & Afrikanskaya Skazka & $\begin{array}{l}\text { Leonid Aristov } \\
\text { / Igor Nikolayev }\end{array}$ \\
\hline 1965 & A Hot Stone & Goryachiy Kamen' & Perch Sarkisyan \\
\hline 1966 & A Proud Little Ship & Gordyy Korablik & Vitold Bordzilovsky \\
\hline 1967 & $\begin{array}{l}\text { The Prophets and The } \\
\text { Lessons }\end{array}$ & Proroki I Uroki & $\begin{array}{c}\text { Vyacheslav } \\
\text { Kotenochkin }\end{array}$ \\
\hline 1968 & 25th, the First Day & 25-ye, pervyy den' & $\begin{array}{l}\text { Youry Norstein / } \\
\text { Arcady Turin }\end{array}$ \\
\hline 1968 & The Eaglet & Orlenok & Vitold Bordzilovsky \\
\hline 1970 & Attention! Woolves! & Vnimaniye, Volki! & Yefim Gamburg \\
\hline 1970 & That We Can Do It & Eto V Nashikh Silakh & Lev Atamanov \\
\hline 1971 & $\begin{array}{l}\text { The Lesson isn't Good } \\
\text { for Him }\end{array}$ & Urok Ne Vprok & Valentin Karavaev \\
\hline 1971 & $\begin{array}{c}\text { The Songs of Fiery } \\
\text { Years }\end{array}$ & Pesni Ognennykh Let & $\begin{array}{c}\text { Inessa } \\
\text { Kovalevskaya }\end{array}$ \\
\hline 1971 & Pioneers Violin & Skripka Pionera & Boris Stepantsev \\
\hline 1971 & $\begin{array}{l}\text { Adventures of the Red } \\
\text { Neckties }\end{array}$ & $\begin{array}{c}\text { Priklyucheniya Krasnykh } \\
\text { Galstukov }\end{array}$ & $\begin{array}{l}\text { Vladimir Pekar / } \\
\text { Vladimir Popov }\end{array}$ \\
\hline 1972 & Ave Maria & Ave Mariya & $\begin{array}{l}\text { Ivan Ivanov-Vano / } \\
\text { Vladimir Danilevich }\end{array}$ \\
\hline 1972 & Plus Electrification & Plyus Elektrifikatsiya & Ivan Aksenchuk \\
\hline 1972 & $\begin{array}{l}\text { The Song About the } \\
\text { Young Drummer }\end{array}$ & $\begin{array}{l}\text { Pesnya O Yunom } \\
\text { Barabanshchike }\end{array}$ & $\begin{array}{c}\text { Vyacheslav } \\
\text { Kotenochkin }\end{array}$ \\
\hline 1976 & $\begin{array}{c}\text { A Legend About the Old } \\
\text { Lighthouse }\end{array}$ & $\begin{array}{c}\text { Legenda O Starom } \\
\text { Mayake }\end{array}$ & Vitold Bordzilovsky \\
\hline 1977 & Go Ahead, Time! & Vpered, Vremya! & Vladimir Tarassov \\
\hline 1979 & The Shooting Gallery & Tir & Vladimir Tarassov \\
\hline 1984 & The Story of a Doll & Istoriya Odnoy Kukly & Boris Ablynin \\
\hline
\end{tabular}

\section{FINDINGS AND INFERENCES}

The findings and interpretations resulting from discourse analysis were made as follows within the framework of the questions and titles revealed by van Dijk in his article Ideological Discourse Analysis. These titles are 'self-identity', 'activity', 'goal', 'norm and value', 'position and relation', and 'resource'.

\section{Self-Identity}

In the movies, two contrasts were constructed as 'we' and 'they'. The permanent content here called 'we' was the society of the Soviet Union. Throughout the historical period, several countries joined and left 'we'. For example, due to the political repression in China during the 1920s, the Soviet Union sided with it, and this was exhibited in films produced at the time, but problems with China in the following years and the rise of Mao Zedong disrupted this union. In movies, Western nations were likewise regularly displayed and excluded as 'they'. As an exception to this, in an anti-Hitler film, A Strong Handshake (1941), Great Britain was contained in the 'we' section. In numerous films, the Eastern Bloc countries were involved in the 'we' class because of the common political opinion and presented as solidarity against the enemy.

Research Article - This article was checked by iThenticate 
In general, communities outside the Soviet Union were 'they', that was, others. 'They' were external threats, and they might differ in movies as a result of the events experienced in the prior years. For instance, in the 1920s, 'they' admitted villains, such as imperial supporters and the Whites, from their own nation, while in the years of World War II, the Nazis were the demons of nearly all films. In another example, the United States demonstrated the most deadly 'they' during the Cold War era, from a country that inspired Soviet animation in the early 1930s and even hosted Soviet animators in the United States, performing film screenings in the Soviet Union.

While some historical personages from Russia's history were held in the 'we' category in the movies, some were regarded as 'they'. Those in the status of 'we' were principally chosen from the establishing years of Russia and from among the figures who gained outstanding achievements in the history of Russia, while those in the category of 'they' were the tsars who persecuted their people and the executives from the last period of the empire. The October Revolution was one of the most flashbacked events in movies, and the themes of patriotism and nationalism in most films produced during the Soviet period were based on it and its effects. Propaganda films were explicitly produced to commemorate and recall the October Revolution on various revolution anniversaries. There were also many allusions to historical people and situations through 'they'. Particularly in films produced versus the United States, racial discrimination was underlined by indicating racism, slave trade, and piracy in the United States history. Again, in movies against the Nazis, there were mentions of concentration camps and racist activities carried out by the Nazis. From this perspective, the Soviet Union was presented as a country where various ethnic minorities coexist peacefully. Hence, propaganda animated films that reveal their cultural diversity, such as Samoyeds, as well as different myths, legends, and tales from their geography, were also produced.

The contrast between 'we' and 'they' was shaped within the framework of specific ideologies. In films that highlight socialism and communism, the enemy was usually capitalist characters. These were politicians, bosses, businessmen, merchants, missionaries, artisans, bourgeois, shareholders, or landowners who threaten and try to destroy the existing system, embodied in specific costumes and accessories, trying to stand out with their pleasures and achievements. The figures of workers, farmers, peasants, soldiers, and pioneers were placed opposite these characters to prove the current system's force. In opposition to fascism, a narrative was formed chiefly of Nazi personalities, and these figures were associated with Hitler both with their physical appearance, such as a Hitler mustache, and with their behavior, such as a Hitler salute. Both members of contrary ideologies were depicted as more animalistic and monstrous than human forms. Soviet ideology characters, on the other hand, were inspirational and influential in human forms. In the pioneer stories, feelings such as courage, not physical strength, were brought to the fore. Besides, as a result of anti-religious policy, clergymen were also recognized part of the 'they' group, but these references to religion were more dominant in the initial years of the Soviet Union.

\section{Activity}

In particular, films that featured socialism and communism focused on the advancement process of the Soviet Union, its breakthroughs in economy and industry, and improvements resulting from five-year plans. Factories, facilities, power plants using workers; vehicles, such as tractors, and investments in agriculture through farmers; the expansion of the army and production of vehicles such as warplanes, tanks via soldiers were presented. As a consequence of this system, the perception of a powerful and patriotic nation was formed in which the state grows and the people live in peace. On the other hand, 'They' were presented as opponents who endeavor to disrupt this system from inside or outside. Stories such as encouraging consumer society, foregrounding personal pleasures, promoting private property, and the American Dream were negated due to the capitalist system and described as the current system's adversary. In anti-fascist films, the Nazis and external enemies were shown as people who attempt to interrupt the system through war and invasion actions. In the movies, the Soviet people were always a

Research Article - This article was checked by iThenticate 
war-ready and robust nation. Apart from soldiers, workers, and farmers, narratives on different social groups in the Soviet Union did not take much place, and in the 'they' group, there were mainly businessmen and soldiers.

In movies where the West, primarily the United States, was displayed as a location, narratives such as the system's disorder, class inequality, racism, and unemployment were created. Black characters were portrayed as people who work in low-paid jobs, were despised, suffered injustice and violence, and were first laid off in an economic crisis. Bosses and politicians were presented as characters who were identified with specific costumes and clothes, thought of themselves in all circumstances, were at the top of the system, drove luxury cars, and led a luxurious life. There were additionally some expressions about how these characters become rich and their process of becoming rich. Some companies' wealth was attributed to the slave trade and colonial activities they did in the past centuries. It was also noticed that some companies arose from actions such as arms trade and weapons industry, stock market, and oil.

\section{Goal}

The 'good' goals of propaganda animations were generally to reveal two opposing systems, praise the Soviet Union, defend the existing system, highlight the advancements in the current policy, and negate the deficiencies of the conflicting ideology. Especially in the beginning years of the Soviet Union, animated films concentrating on more fundamental issues were carried out to inform the public, introduce the current system, and ensure continuity. In the following years, with animation techniques development, narration opportunities were expanded, different animation types emerged, and more qualified works were created. Throughout the history of the Soviet Union, propaganda films were designed in order to keep the system's continuity and the memory of the people alive, and references were made to events such as the October Revolution and the Great Patriotic War, which were regarded as the country's historic victories, and depictions of the enemy, principally through the United States and Nazi Germany, were renewed continuously. Over the years, it was observed that anti-Nazi and Holocaust implications developed into anti-Neo-Nazi, and criticism of racism and the American Dream in the United States evolved into many events such as the Vietnam invasion. While these film examples were applied with Soviet characters like soldiers, workers, and farmers throughout the war years, after the 1960 s, they were often made on pioneer stories to keep the mind of the new generation alive.

\section{Norm and Value}

The principal purpose of all activities in Soviet propaganda animations was the Soviet Union. The Soviets' norms and values were based on socialist society, and the films described this system as the most excellent, appropriate, and humane model. Hence, what was described as 'true' in the narratives in propaganda films were part of the system and ensured its continuity. Apart from these, the traditional values of Soviet society, such as music, costumes, historical figures, were affirmed continuously in the movies. Modern systems and structures were approached at a distance, and they were identified with the West; thus, narratives were built through the traditional-modern conflict. While constantly negating values and behaviors such as individualism, luxury consumption, property, personal pleasures, greed, selfishness, laziness, vanity, fashion, arrogance, jealousy, values such as collectivism, courage, austerity, diligence, and self-sacrifice stood out as affirmed values perpetually.

The theme of patriotism was featured in movies as a meaningful sense that holds the country and society together. Both the empire supporters, who were portrayed as internal enemies, and the capitalists and fascists, who were depicted as external invaders, were shown as devoid of this feeling. Since Soviet society was described as an exemplary society with no class struggle and distinction, was egalitarian, lived in peace, adhered to its traditions, and prioritized community rather than the individual, these values were continually called 'true'. On the other hand, the Western system was utterly 'wrong' not only in terms of politics, economy, and society but also culture and art. This attitude softened over time while being given more sharply in the initial years of the Soviet Union. For instance, jazz and rock music,

Research Article - This article was checked by iThenticate 
which were denied as Western music in the early years, were used in some Soviet animations in the 1970s. Religious expressions were among the values reported as 'false'. Because the USSR had an antireligious policy, notably in the earliest years, this approach was reflected in the films. This behavior was applied to Christianity and other local beliefs such as shamanism and idolatry.

\section{Position and Relation}

The most used location in movies was the Soviet Union. The 'good' side of the good-bad struggle set in the films was met by the Soviet Union and other allied states. The 'bad' side was Western countries, where the USA and Nazi Germany stand out, and Japan, where the USSR occasionally went to war in the East. Elements such as symbol buildings, advertisement signs, and flags were used to define the country. Manhattan, Times Square, the Statue of Liberty, Wall Street, and the Chrysler Building were often featured in the movies to draw the United States. The use of these structures and places in the animations of the Soviet Union, which was the biggest competitor of the United States at the time and where the mass media was not very widespread, could be noticed as confirmation of the success of the United States and Hollywood in building brands worldwide and that the Soviets recognized this achievement.

Even though the Soviet Union, USA, and Nazi Germany took place on the central axis in the films, several states were also in sub-branches. According to historical periods, the Soviet Union was registered in collaboration with countries such as China, Vietnam, Great Britain, Czechoslovakia, Poland, Bulgaria, East Germany, Hungary, Mongolia, Yugoslavia, and Romania. Nazi Germany or the United States were more frequently portrayed as a singular threat. In some movies, other fascist leaders appeared alongside Hitler, and in some, the threat of invaders from both the West and the East was combined. In some animations, it was observed that the bourgeois class, who fled the country at the end of the revolution, cooperated with external forces, and while doing this, they exhibited animalistic attitudes by giving up their own identities. Thus, while socialism held the countries united on the 'good' side of the polarization collectively, the countries on the 'bad' side formed a group based on their hostility towards these 'good' countries.

\section{Resource}

In Soviet propaganda animations, the Soviet Union were presented as a flawless socialist state without any deficiencies, providing equal opportunities and resources to its citizens, without unemployment, racism, and exploitation, continually developing in the field of economy and industry, self-sufficient in agriculture and capable of manufacturing its military equipment. Studies in fields such as electrification, space studies, and technology were introduced in detail in the movies, and the aid made to other nations to show the strength of the state was also discussed. The economic possibilities brought by the socialist state were particularly highlighted, and these chances were listed on issues such as income inequality in the capitalist system, the problem of unemployment, and class distinction. Issues such as the stock market, luxury consumption, credit, borrowing were introduced to the audience by exemplifying them through life in the USA, and narratives were made on how these factors can affect human life and living conditions and how harmful the capitalist system is. Therefore, animations exposed all the opposing system's shortcomings, making their system more dominant on the scale.

Personages such as Vladimir Lenin, Joseph Stalin, and Karl Marx were frequently featured in films as sources and locomotives of the socialist structure. Especially in the earliest period movies, straight narratives were created in which the book Kapital was shown, the Russian Communist Party gathered members, and government bonds were granted to the public. It was observed that symbolic elements such as the book Mein Kampf and the song Oh du Lieber Augustin were used in the stories against the Nazis. The sources of the capitalist system were the trademarks that are the reflections of the consumer society. Brands such as Coca-Cola, Cadillac, Camel, Pepsi Cola, Ford, General Motors, Lincoln, AVIS, Boeing, Shell, Warner Bros were also used in movies as sources outlining the West. In the animations,

Research Article - This article was checked by iThenticate 
the people at the top of the capitalist system were shown using these brands. Moreover, these brands were presented to the people as objectives to be reached through billboards.

\section{CONCLUSION}

This study was prepared to identify the ideological discourses used in Soviet animated films and to interpret these inferences. Since Soviet animations were nearly discovered after the dissolution of the Soviet Union, research in this area is minimal. This investigation contributes to the field from this perspective and makes a classification for propaganda movies by knowledge collected from various sources.

The article's ideological discourse analysis method was applied by viewing Teun A. van Dijk's article titled Ideological Discourse Analysis. As ideological discourses were examined within the study's extent, only short films with propaganda content were counted among Soviet animations, and the scope of the study was restricted. In determining these movies, the Encyclopedia of Local Animation prepared by Sergey Kapkov and Animator.ru animation database sponsored by the Federal Agency of Press and Mass Media of the Russian Federation were applied. The films discussed within the study's scope were taken from among the films produced by Soyuzmultfilm, the official animation studio of the Soviet Union. For this reason, the production period of the films considered is between 1936 and 1991. The findings obtained from the films produced for propaganda purposes were analyzed by van Dijk's approach towards representing the ideological groups in a 'positive' way and those outside themselves in a 'negative' way. The decisions of discourse analysis were evaluated according to the headings 'selfidentity', 'activity', 'goal', 'norm and value', 'position and relation', and 'resource' mentioned in the article Ideological Discourse Analysis, and the ideological discourses in Soviet animated cinema were examined.

According to the results, the movies examined formed two separate poles as 'we' and 'they', while the Soviet Union as 'we' was considered, and two distinct approaches, anti-Western and anti-Nazi, were accepted as 'they'. In the 'we' narrative, socialism and communism were praised; capitalism, imperialism, and fascism set the other polarization factors. It has been observed that the 45 short films explored within the scope of the study can be divided into three groups, which are 'Films Against Capitalism and Imperialism', 'Anti-Fascist Films' and 'Films with Praise for Socialism and Communism', within this framework. These movies, which were analyzed one by one in the discourse analysis, were examined within the frame of specific themes: location, personage-character, costume-accessory, business lifeeconomy, and social features-historical events, religion, symbol-brand, color-light, and visual languagetechnique.

The conclusions and subsequent inferences showed that Soviet animated films with propaganda content were documents reflecting the dates they were produced and the periods they dealt with. From this point of view, it can be assumed that the primary purpose of films is to reflect the current political structure and ideology, create this awareness in the people they reach, and contribute to creating consciousness in the nation. It can be inferred that this memory is more comprehensive than other film genres thanks to the broader expression possibilities of animations. Consequently, from this study, it can be quickly concluded that Soviet animation cinema, which is approximately the same age as the Soviet Union and exhibits the consequences and reflections of the political ideology in which it is located as a product of a systematic mechanism, creates a kind of cultural memory that displays the political history and social culture of the Soviets by creating ideological discourses.

Research Article - This article was checked by iThenticate 


\section{REFERENCES}

Bendazzi, Giannalberto. (1995). Cartoons: One Hundred Years of Cinema Animation. Indiana University Press.

Bocharov, Victor. (2004). A Belated Premiere, Documentary. Russia: Gosfilmfond Rossiyskoy Federatsii.

Eisenstein, Sergey. (1993). Sinema Sanatı. Çev. Nilgün Şarman. İstanbul: Payel Yayınevi.

Fairclough, Norman. (2001). "Critical Discourse Analysis as a Method in Social Scientific Research". Introducing Qualitative Methods: Methods of Critical Discourse Analysis. SAGE Publications.

Kapkov, Sergey. (2006). Entsiklopediya otechestvennoy mul'tiplikatsii. Moscow: Algoritm-kniga.

Lozhkov, Dmitry. (2013). "Rol' propagandy v Sovetskom Soyuze po probleme formirovaniya obshchestvennogo mneniya po voprosam sovetsko-amerikanskikh otnosheniy v 1970-ye gody". Gosudarstvennoye upravleniye Elektronnyy vestnik. 38, s. 189-200.

Moritz, William. (1997). "Ladislas Starewitch". The Oxford History of World Cinema. Oxford University Press.

Sawicki, Mark. (2010). Animating with Stop Motion Pro. Oxon: Taylor \& Francis.

Sevindi, Koray. (2020). Sovyet Propaganda Animasyonlarında İdeolojik Söylem. Marmara Üniversitesi Sosyal Bilimler Enstitüsü, Yayınlanmamış Doktora Tezi.

Taylor, Richard. (1998). Film Propaganda: Soviet Russia and Nazi Germany. New York: I. B. Tauris. van Dijk, Teun. (1995). "Ideological Discourse Analysis". Interdisciplinary Approaches to Discourse Analysis (The New Courant). Vol: 4, Helsinki: University of Helsinki - Department of English.

\section{ELECTRONIC RESOURCES}

URL-1 Animator.ru Animation Database. https://www.animator.ru/db/?ver=eng\&p=films (Last Accessed: January 10, 2021). 